\title{
KRYZYS DEBATY PUBLICZNEJ W POLSKIEJ DEMOKRACJI A POP-POLITYKA
}

\begin{abstract}
Streszczenie
W artykule jest dyskutowany problem kryzysu debaty publicznej w Polsce, który przejawia się w agresywnej konfrontacji liberalnych i konserwatywnych elit władzy. Językowe praktyki piętnowania i wykluczania przeciwników ilustrują zmianę reguł komunikacji politycznej w następstwie wykorzystania cyfrowego obrazowania i replikowania nowych form przekazu. Autor przyjmuje definicję pop-polityki jako sieciowego ,profilowania orientacji politycznych" w dyskursie publicznym prowadzonym za pomocą cyberkomunikacji i mediów społecznościowych. Pop-politykę można opisać jako rywalizacyjny spektakl medialny nakierowany na: neutralizację wizerunków politycznych, dyskredytację społecznego oporu, zniechęcanie do udziału w protestach wobec władzy. W niniejszym artykule analizowana jest natomiast jako zestaw praktyk komunikacyjnych wyrastających ze sprzeczności procesów globalizacji, neoliberalnej ekonomii i strukturalnej dekompozycji obywatelskiej opinii publicznej. Pop-polityka łączy reguły rytualizacji dyskursów, uwiedzenia publiczności z siłą resentymentów społecznych oraz imitacyjną rywalizacją i poszukiwaniem „kozłów ofiarnych”. Rywale polityczni budują domeny symboliczne w celu identyfikowania uczestników kulturowej wspólnoty. Polski konserwatyzm zdominował dyskursy pop-polityki kodami etnicznego patriotyzmu, afirmacji narodowych tradycji i paternalizmu władzy organizującej wspólnotę i udzielającej schronienia przed multikulturowymi zagrożeniami.
\end{abstract}

* Dr hab., Zakład Socjologii Organizacji, Gospodarki i Metodologii Badań Społecznych, Instytut Socjologii; e-mail: bamid@wp.pl 
Słowa kluczowe: opinia publiczna, spektakle polityki, wirtualizacja dyskursów, profilowanie orientacji politycznych, domeny symboliczne, resentyment, konserwatywny paternalizm

\section{WPROWADZENIE - KRYZYS POLSKIEJ DEBATY PUBLICZNEJ}

Język polskiej polityki od początku transformacji ustrojowej zdominowały konfrontacyjne narracje ugrupowań partyjnych, budujących swoje tożsamości na argumentacji podważającej społeczne intencje i etyczną prawomocność ideologicznych oponentów. Początkowo ideologizacja sporów wynikała z wzajemnego oskarżenia się ugrupowań partyjnych o odpowiedzialność za społeczne koszty neoliberalnych reform gospodarczych, narzuconych „szokową terapią Balcerowicza". Politycy debatujący w mass mediach stawiają ogólne zarzuty, krytykując przyzwolenie rządzących na „złodziejską reprywatyzację”, zdradę ideałów „Solidarności” przy okragłym stole, służalczość liberalnych elit władzy wobec „postkomunistycznego układu” lub wobec unijnej „brukselskiej biurokracji”. Tezy o „przeciwstawianiu się liberalnej nowoczesności i kulturowej otwartości” kontrowano atakami na kosmopolityczne elity odpowiedzialne za „wyprzedawanie wartości” polskiej kultury i ,niszczenie katolickich tradycji narodu”.

Ostrość polemiczna i reguły negatywnej propagandy politycznej same w sobie nie są obce komunikacyjnej kulturze w demokratycznej deliberacji. Rozumie się ją za Jürgenem Habermasem czy Johnem Rawlsem jako pragmatyczny dyskurs stron poszukujących poprzez publiczny dialog racjonalnej i sprawiedliwej mediacji pomiędzy swoimi stanowiskami [Abramowicz 2011:216-219]. Zdawać by się mogło, że problemy debaty politycznej w młodej i nieskonsolidowanej demokracji będą przezwyciężane w praktykach rozbudowy obywatelskiej tożsamości Polaków w ramach europejskiej wspólnoty narodów. Jednak od czasu wstąpienia Polski do Unii Europejskiej „niepokoje związane z polską demokracją” uległy jedynie nasileniu, a ich konsekwencją jest podział w dyskursie politycznym na zwolenników i przeciwników wizji III i IV Rzeczpospolitej [Kurczewska 2004: 424-425; Raciborski 2011: 180]. Podział ten ma charakter moralistyczno-tożsamościowy, wyraża rozczarowanie transformacją i służy mobilizowaniu elektoratów wokół neoliberalnych lub neokonserwatywnych wartości, a nie programów [Jasiecki 2008: 240-241]. Główni partyjni animatorzy dyskursu politycznego, Platforma Obywatelska oraz Prawo i Sprawiedliwość, nie troszczą się o debatę nad publicznym stanem idei wpisanych w swoje nazwy. Nie kształtują demokratycznej kultury politycznej, a jedynie zagospodarowują lęki społeczne, pragmatycznie 
zarządzając „polityczną technologią” [Gąciarz 2008: 103]. Krzysztof Tyszka, analizując antagonistyczne narracje $\mathrm{w}$ prawicowej prasie, prezentującej III RP jako „rządy układu”, a IV RP jako uosobienie uczciwości i patriotyzmu, wskazuje na budowanie obrazu przeciwnika politycznego za pomocą piętnującej moralistyki. Takie zredukowanie treści propagandowego przekazu ma na celu instrumentalne kreowanie wizerunku wroga - ucieleśnianego przez liberałów - i sprawia że „wszelkie programy, idee i decyzje polityczne sprowadzane zostają do kategorii dobra i zła, wyznaczających biegunową wizję świata" [Tyszka 2007: 59].

Dysponujemy bogatą literaturą dokumentującą psychologiczno-socjologiczne, politologiczne, językoznawczo-semantyczne cechy i uwarunkowania piętnujących oraz tożsamościowych praktyk perswazyjnych, stosowanych w polskim dyskursie publicznym ${ }^{1}$. Uwagę zwraca znaczący segment literatury społeczno-historycznej i komentatorskiej, publikowanej przez tak zwanych „niezależnych” dziennikarzy oraz zaangażowanych uczonych, wspierających ideologicznie głównie prawicowych aktorów sceny politycznej. Ich walka o medialną wolność opinii i instytucjonalną pozycję narodowo-konserwatywnej publicystyki jest zjawiskiem cennym dla prowadzenia debaty publicznej. Niepokoi wysoki poziom ich aksjologicznego fundamentalizmu, autorytatywne piętnowanie demokratycznego liberalizmu oraz polityczna służalczość w kreowaniu narodowo-katolickiej propagandy. Ma to służyć odbudowie intelektualnych tradycji myśli narodowej, a zarazem być ideową odpowiedzią konserwatystów na zagrożenie Polski postnowoczesną kulturą i globalizacją.

Bezpośrednią funkcją polityczną tej literatury jest polemika z praktykami władzy Platformy Obywatelskiej. Cechuje ją duża moc perswazyjna, ale też, sprofilowana jedynie na krytykę, jednostronna argumentacja ${ }^{2}$. Autorzy tych

1 Odwołuję się tu m.in. do prac: J. Kurczewska (red.), Kultura narodowa i polityka [2000]; J. Kurczewska, Patriotyzmy polskich polityków [2002]; R. Garpiel i K. Leszczyńska (red.), Sztuka perswazji [2004]; T. Walas (red.), Życie polityczne w Polsce [2004]; R. Markowski (red.), Populizm a demokracja [2004]; M. Gierula (red.), Władza. Media. Polityka [2006]; M. Sokołowski (red.), Media w Polsce. Pierwsza władza IV RP? [2007]; A. Duszak, N. Frairclough (red.), Krytyczna analiza dyskursu [2008]; M. Czerwiński, P. Nowak, R. Przybylska (red.), Język IV Rzeczypospolitej [2010]; M. Czyżewski, S. Kowalski, A. Piotrowski (red.), Rytualny chaos. Studium dyskursu publicznego [2010]; M. Graszewicz, Polski system polityczny. Semantyki i struktury komunikacji politycznej [2011]; J.H. Kołodziej, Wartości Polityczne [2011]; M. Jarosz (red.), Polskie bieguny [2013]; L. Szczegóła. Bierność obywateli [2013]; P. Żuk. Kultura a polityka [2015]; L. Polkowska, Język prawicy [2015].

2 Jej przykładami są choćby następujące książki: A. Pawełczyńska, $O$ istocie narodowej tożsamości. Polacy wobec zagrożeń [2010]; Z. Krasnodębski, Już nie przeszkadza [2010]; K. Jaskułowski, Wspólnota symboliczna w stronę antropologii nacjonalizmu [2012]; A. Zybertowicz, 
polemicznych rozpraw legitymizują swoje stanowiska wnioskami z akademicko ugruntowanych prac, takich jak: Demokracja peryferii Zdzisława Krasnodębskiego (z 2003 roku), Podziat postkomunistyczny. Spoleczne podstawy polityki w Polsce po 1989 roku Mirosławy Grabowskiej (z 2004 roku) czy Za kulisami. Szkice o władzy, interesach i bezpieczeństwie (z 2012 roku) pod redakcją K. Pietrowicza i P. Stankiewicza (z tekstem Andrzeja Zybertowicza o powiązaniach antyrozwojowych grup interesów i politycznej pogoni za rentą w zarządzaniu publicznym).

Zaangażowanie ideologiczne ludzi nauki w debatę polityczną nie stanowi problemu, aż do czasu kiedy przyłączają się oni do ataku na opozycyjne ośrodki opinii publicznej. Akademiccy liderzy politycznego dyskursu sami służą wykluczaniu z niego reprezentantów tak zwanego „lewactwa”’3 lub „resortowych dzieci”" używając w komunikacji publicznej nowomowy i obraźliwych epitetów. A takie praktyki w ostatniej dekadzie są intensywnie aktywizowane i przenoszone z mass mediów do przestrzeni komunikacyjnej Internetu. Stosowanie społecznościowych form wirtualnej komunikacji służy obecnie wszystkim stronom sporu publicznego do zaostrzania walki politycznej. Nowe wirtualne środki wyrazu oddziałują perswazyjnie, łącząc obraz z krótkimi komunikatami o charakterze ironicznym, oskarżycielskim lub demaskatorskim; jednocześnie w sposób swobodny, bez autoryzacji, manipulują informacjami i anonimowymi komentarzami.

J. Lichocka. III RP Kulisy systemu [2013]; A. Zybertowicz, M. Grutowski, R. Sojak, Państwo Platformy. Bilans zamknięcia [2013]; M. Nykiel, Pułapka gender. Karty kontra orty - wojna cywilizacji [2012]; A. Gelberg, Miazmaty III RP [2017]; Rok dobrej zmiany Wywiady M. Sutkowskiego [2017].

3 Kategoria odnoszona do skrajnej lewicy, używana w debacie ostatniej dekady przez środowiska prawicowe jako polityczny „epitet” wobec wszystkich tych, których uznaje się za sympatyków postkomunistycznego układu III RP. Jej popularność w publicystyce i propagandzie dziennikarzy związanych z mediami służebnymi wobec Prawa i Sprawiedliwości sprowokowała dra Sławomira Czapnika do zorganizowania na Uniwersytecie Opolskim seminarium dla studentów [por. http:// opole.wyborcza.pl/opole/1,111632,20064486,w-polsce-latwo-zostac-lewakiem-ale-co-to-znaczy. html?disableRedirects=true [dostęp: 20.08.2018]. Lukasz Drozda w książce Lewactwo. Historia dyskursu o polskiej radykalnej lewicy [2015] analizuje dyskursywne użytkowanie tego pojęcia jako symbolicznego znaku określającego własne miejsce na mapie podziałów ideologicznych, stosowanego autoironicznie oraz w celu obrażenia przeciwników prawicy i narodowo-katolickich wartości.

4 Głośna seria oskarżycielskich książek Doroty Kani, Jerzego Targalskiego i Macieja Marosza: t. 1. - Resortowe dzieci - Media [2013]; t. 2. - Służby [2015] i t. 3. - Politycy [2016], uderzających $\mathrm{w}$ autorytety establishmentu i mass mediów mające rodzinne powiązania $\mathrm{z}$ funkcjonariuszami władzy komunistycznej i tajnych służb PRL. Autorzy czerpią energię z dokumentowania roli nieformalnych „układów” i żydowskich korzeni ludzi postkomunistycznych elit, jako powodów ich przeciwstawiania się procesom lustracji oraz „repolonizacji” mediów publicznych w czasie rządów IV RP 2005-2007. 
Budowane są sieciowe kanały komunikacyjne służące systematycznemu prowadzeniu krytyki oponentów przez polityków-blogerów. Niektórzy politycy ukrywają się za pseudonimami lub opłacają tak zwanych trolli, atakując w sieci przekazy wybranych liderów konkurencyjnych opinii i profile działaczy partyjnych oraz ich aktywnych sympatyków. Oprócz produkowania propagandowej nowomowy, łączonej ze stosowaniem insynuacji, „fake newsów” i „,mowy nienawiści”, zaangażowani politycznie blogerzy ${ }^{5}$ są cytowani przez główne media publiczne, a nawet zatrudniani jako ich dziennikarze lub doradcy ministrów do spraw komunikacji. Publikują też własne książki, wchodzące w obieg dyskursów politycznych, a więc funkcjonują jako wpływowi nadawcy. Przykładem takiego przenikania się komunikacyjnych ról i form obecności może być książka z felietonami Waldemara Jana Rajcy pt. $W$ demokratycznym chaosie. Jak demoliberalizm niszczy Polskę. Autor ${ }^{6}$ atakuje liberalną demokrację jako rzekomo obcą „cywilizacji łacińskiej”, a także narzędzie moralnej „relatywizacji życia społecznego”, które konfliktuje „obywateli” i ,jest zaprzeczeniem państwa prawa” [2014: 5-7].

Przekazy angażujące odbiorców w jednostronną argumentację, o silnym nasyceniu ocenami, wartościujące w manichejski sposób funkcjonowanie instytucji politycznych, moralizujące na temat cywilizacyjnego konfliktu liberalizmu z konserwatyzmem, są czymś więcej niż populistyczną, instrumentalną grą polityczną. Wirtualne mass media w szczególnym stopniu sprzyjają korzystaniu ze stereotypizacji treści, z eksponowania w krótkich przekazach negatywnych emocji i wyobrażonych podziałów, piętnowania wrogich „ukrytych układów” i projektowania zagrożeń społecznych, krytykowania oponentów za insynuowane intencje oraz przekręcane lub wyrywkowo cytowane wypowiedzi. Przekazy wykorzystujące te zabiegi mają wielką siłę atakowania i kwestionowania autorytetów opinii publicznej.

O zmianie społecznych norm komunikacji politycznej, sięgającej po nowe media i technologie 2.0 Web, preferujące wizualność, symboliczność i negatywną emocjonalność dyskursu sieciowych społeczności - pisze Agnieszka Kampka [2014: 145-147]. Zdaniem autorki kryzys debaty publicznej w Polsce nie jest wyrazem jej schyłku, lecz skutkiem transformacji mediów związanej

5 O wykorzystywaniu opinii wpływowych blogerów politycznych (głównie o sympatiach prawicowych, takich jak np. Kataryna, Rybitzky, Tomasz Terlikowski czy Azrael, Bazinga) świadczą publikowane rankingi ich wpływu [por. http://wiadomosci.dziennik.pl/opinie/artykuly/149901,najlepszeblogi-polityczne-wedlug-zaremby.html]. Opozycyjnymi blogerami są zaś często sami politycy [http://nietylko.natemat.pl/87261,ranking-blogow-politykow-blogerzy-natemat-w-czolowce, dostęp: 25.08.2018].

6 Uznany za najlepszego blogera 2009 roku polityk partii UPR i Kongresu Nowej Prawicy. 
z ekspansją środków budowania retoryki wizualnej, która wzmacnia politykę protestu [2004: 186]. Sposobem na wyjście z kryzysu ma być postulowana przez badaczkę zmiana postaw uczestników debaty - polityczni adwersarze powinni dostosować nowe środki wyrazu do poszukiwania wspólnych znaczeń i przejść od ekspresyjnego obrazowania swych racji w celu manipulowania odbiorcą do rozumienia oponentów [2014: 137]. Jej konkluzje oparte są na oczekiwaniach wynikających z założeń deliberatywnego modelu prowadzenia demokratycznego sporu. W rzeczywistości obserwujemy zerwanie dialogu stron sporu politycznego operujących celowo koncepcją wroga, co stanowi przejaw głębokiego kryzysu debaty publicznej i wymaga wyjaśnienia jego przyczyn.

\section{HIPOTEZA POP-POLITYKI JAKO SIECIOWEGO PROFILOWANIA ORIENTACJI POLITYCZNYCH}

Pragmatyczna ocena jakości dyskursów narzuca wniosek, że konfliktowe praktyki w komunikacji politycznej, cyniczne stosowanie zakamuflowanego kłamstwa i emocjonalnego ataku na status społeczny oponentów nie wynikają z niskiej kultury posługiwania się narzędziami obrazowej, tabloidowej komunikacji. Istnieją ogólniejsze przesłanki konfliktowej dynamiki dyskursu publicznego w społeczeństwie doby Internetu i mediów sieciowych. Manuel Castells w książce Władza komunikacji stwierdza, że władza polityczna opiera się na kontroli komunikacji z wyborcami i na przeciwdziałaniu kontroli umysłów publiczności przez opozycyjne siły. Cyfrowe media szczególnie sprzyjają realizacji takich celów dzięki: obrazowemu ramowaniu i emocjonalnemu wyjaskrawianiu wybranych newsów, wyznaczaniu hierarchii tematów, dezinformowaniu publiczności, aktywizowaniu „kultury strachu” i eksponowaniu „zagrożeń”, metaprogramowaniu wartości, wprowadzaniu nowych kodów narracyjnych i instrukcji ich symbolicznego organizowania, zindywidualizowanemu programowaniu treści komunikacji sieciowej, kreowaniu form symbolicznego oporu społeczności sieciowych wobec ośrodków panującej władzy [Castells 2013: 17-18, 58-60].

M. Castells nazywa ten model dyskursywnego oddziaływania masowa komunikacja zindywidualizowana [2013: 75]. Jego analiza wzmacnia dyskutowaną tu hipotezę o ukształtowaniu się nowych mechanizmów profilowania orientacji politycznych elektoratu poprzez negatywne narracje i dyskredytowanie wizerunków oponentów za pomocą zwirtualizowanego spektaklu pop-polityki. Koncepcja pop-polityki, jako spektaklu wizerunków i profilowania opinii obywatelskich w celu manipulacji ich orientacjami politycznymi, zakłada świadome zarządzanie przez ośrodki polityczne rozpadem debaty publicznej na zrytualizowane retorycz- 
nie i negatywnie pozycjonowane dyskursy. Władza uprzywilejowuje określone dyskursy, aktywizuje retencję treści dyskursów rezonujących z tożsamością podmiotów objętych przekazem, filtruje sprzeczne z nimi dyskursy i wzmacnia treści afirmujące własne praktyki, werbuje grupy społeczne i organizacje przez propagowanie ich członków, upajanych treścią lub retencją politycznie preferowanego dyskursu. Takie mechanizmy wspomagania i reprodukcji dyskursywnych narracji opisuje Bob Jessop, badacz kulturowej ekonomii politycznej [Jessop 2008: 133-134].

Pop-polityka będzie tu definiowana jako rywalizacyjny spektakl medialny, profilujący jawnie oraz zakulisowo orientacje polityczne uczestników komunikacji sieciowej z wykorzystaniem wirtualnych mediów dla kreowania wizualnych oraz emocjonalnych form negatywnego dyskursu publicznego, a skierowanych na neutralizację politycznych wizerunków oponentów i dyskredytację społecznego oporu wobec liderów i działań własnych ugrupowań politycznych.

Pop-politykę proponuję analizować jako zestaw praktyk komunikacyjnych wyrastających ze sprzeczności globalizacji neoliberalnej ekonomii i strukturalnej dekompozycji opinii publicznej, które zwrotnie oddziałują na polskie wewnątrzsystemowe konflikty. Sam fakt eksponowania przejawów cywilizacyjnego napięcia pomiędzy liberalną nowoczesnością a polskim konserwatyzmem wskazuje na zderzanie się ogólnych czynników ze sprzecznościami wewnętrznymi. Wymaga to sformułowania pytań o źródła mechanizmów: aktywizujących funkcje pop-politycznego dyskursu aktorów gry medialnej, napędzających negatywną dynamikę sporów wokół ich wizerunków, pozorujących (lub rytualizujących) debatę nad zgłaszanymi publicznie racjami.

Pop-polityka wywołuje ważny problem - pytanie o powody odrzucenia deliberatywnego modelu dialogu stron na forum opinii publicznej. Wstępna odpowiedź mogłaby brzmieć, że taki dialog zakłada symetrię statusu debatujących publicznie aktorów, jako reprezentantów heterogenicznej kulturowo i światopoglądowo publiczności. Tymczasem dysfunkcje języka debat w III i IV RP można za Radosławem Marzęckim określić jako utrwalanie w polskim dyskursie politycznym habitusowego wzoru komunikacji opartego na syndromie podziału świata na część dobrą i złą; na tę reprezentowaną przez „swoich” i tę „obcych”, którzy opisują struktury rzeczywistości innym językiem i dysponują własną ,,wspólnotą komunikacyjną" [Marzęcki 2010: 114]. Aktorzy gry politycznej, w tak definiowanym polu dyskursu, nie zmierzają do poszukiwania kompromisów między różnymi interesami, lecz prezentują się jako jedyni reprezentanci „liberalnej kultury obywatelskiej" lub patriotyczno-chrześcijańskiej prawicy wyrażającej suwerenny „interes narodu”. Organizowanie takiego spektaklu politycznego odwołuje się do 
niezadowolenia obywateli z demokracji i braku zaufania do instytucji państwa. Sięga więc po populistyczne narracje i emocje mas, uderzające $\mathrm{w}$ dominujące elity jako „zakorzenione” w ukrytych sieciach interesów, obnażane za pomocą retoryki partykularno-nacjonalistycznej lub socjalnej krzywdy „większości” zwykłych obywateli [Markowski 2004: 22-23].

Nasuwa się pytanie uszczegóławiające - dlaczego polscy politycy nie podjęli się budowania partycypacyjnej kultury obywatelskiej, lecz świadomie przyjęli i praktykują spektakl populistycznej mobilizacji sił społecznych, niezadowolonych z zachodzących przemian? Odpowiedzi poszukamy w teoriach ,rytualizacji dyskursu” oraz „rozrzedzania” deliberatywnej demokracji w społeczeństwach późnej nowoczesności i ,mimetyzmu” rywalizacji w kulturze konsumpcjonizmu.

\section{TEORETYCZNE ANALIZY NOWYCH RAM DYSKURSU PUBLICZNEGO}

Badacze komunikacji politycznej wskazująże: „Funkcją dyskursu jest kreowanie kulturowej rzeczywistości danej formacji, będąc przez nią generowanym z zastanego lub nowego materiału, powodując i zapewniając jej dyskretność, a więc tworząc ją i będąc przez nią tworzoną. Dyskursy są swoistymi koniecznymi i obowiązującymi nawykami wypowiadania się, a normatywność dyskursu nie może być wyprowadzana z systemu językowego" [Graszewicz 2011: 59 - za teorią komunikacji Fleischera 2007]. Tezę tę traktuję jako wyjściowe założenie dotyczące funkcji dyskursów, które nie tylko w Polsce stały się swoistą przestrzenią komunikacyjnej walki o tożsamość stygmatyzujących się ideologicznie stron sceny politycznej.

Koncepcję uwzględniającą dramaturgiczny wymiar komunikacyjnej konfrontacji dyskursów publicznych przedstawia obszerne studium inscenizacji sporu politycznego pt. Rytualny chaos pod redakcją Marka Czyżewskiego, Sergiusza Kowalskiego i Andrzeja Piotrowskiego [2010, pierwsze wydanie - 1997]. Wyróżniono w nim cztery mechanizmy dyskursu publicznego: porozumienie, ceremonię, dramat społeczny i rytualny chaos, które regulują trzy powiązane ze sobą typy dyskursów: dyskurs publiczny (obejmuje mniej lub bardziej zinstytucjonalizowane wystapienia na forum publicznym obywateli jako uczestników komunikacji społecznej), dyskurs polityczny (pojmowany jako przekaz węższego kręgu tzw. elit symbolicznych, zakorzenionych w profesjonalnych opiniotwórczych środowiskach i mass mediach, łączących debatę społeczno-kulturową, moralną czy ekonomiczną z funkcjonowaniem władzy i instytucji politycznych) oraz dyskurs polityki (wypowiedzi osób należących do elit władzy i osób pełniących 
funkcje oraz role polityczne w systemie rządzenia społeczeństwem) [Czyżewski 2010a: 22-29]. Wiodąca idea tej analizy opiera się na wyróżnieniu typów argumentacji, jakie podejmują aktorzy sporu publicznego toczącego się w obrębie elit symbolicznych i elit władzy. Są to: głos „światłego obywatela”, wyrażany jako stanowisko „eksperta” lub „mędrca” oraz głos „rzecznika” idei czy narracji politycznej. Dzięki tym narzędziom, traktowanym w różnym stopniu instrumentalnie, uczestnicy medialnej debaty obsadzają się w rolach zaangażowanego ideowo reprezentanta określonych „opinii, potrzeb i interesów” lub wyraziciela głosu „ludu” czy „dominującej większości” [Piotrowski 2010: 38-40].

Rytualizacja polskiego dyskursu publicznego jest w niniejszym artykule wyjaśniana poprzez efekt specyficznej skłonności do jednostronnej argumentacji - włączania trybu wypowiedzi „rzecznika”, jako aksjologicznie arbitralnego głosu ,rzecznika narodu”. Obsadzanie się w takiej roli oponentów politycznych, przywołujących wolę większości narodu i prezentujących się jako jedyni wyraziciele jego tożsamości lub interesów, prowadzi do zawłaszczania pola argumentacji. Typowe jest operowanie racjami absolutnymi, odrzucającymi wszelkie krytyczne wypowiedzi oponentów niezależnie od tego, na jakie argumenty i na jakie autorytety się oni powołują. Efektem utrwalającym rytualizację takich dyskursów jest przejście polityków od strategii przekonywania do skuteczniejszej strategii ,uwodzenia” elektoratu dzięki wzbudzeniu zaufania do dramaturgii własnej autoprezentacji [Piotrowski 2010: 40-41]. Zanik dialogu i czerpanie energii z dyskredytacji przeciwnika, z jego symbolicznej degradacji, staje się efektem praktykowania aksjologiczno-godnościowej dialektyki „my-oni”. W tym autoprezentacyjnym dyskursie „rzecznicy” racji większości społeczeństwa kierują się wartościami, a „inni” - jako „obcy” - motywami własnych korzyści i grupowych interesów [Piotrowski 2010: 43].

Marek Czyżewski, argumentując o rytualizacji dyskursu jako przemyślanej strategii komunikacyjnej elit politycznych - ulegających ,uwiedzeniu” ze strony zmęczonych mas, które pragną głównie spokoju i dostarczania im rozrywki - odwołał się do teorii Jeana Baudrillarda. Sednem jego idei „uwiedzenia” jest stwierdzenie, że „to nie masy odbiorców są manipulowane i «uwodzone» przez współczesne środki masowego przekazu, lecz odwrotnie - środki masowego przekazu ulegają manipulacji i «uwiedzeniu» przez masy, którym nie zależy na niczym innym, aniżeli na tym, by pozwolono im na bierność i milczenie" [Czyżewski 2010b: 63].

Zastanowienie może budzić kategoryczność tezy Baudrillarda rozwijanej w pracy $W$ cieniu milczącej większości, że „,masy w sposób skandaliczny stawiają opór owemu imperatywowi racjonalnej komunikacji. (Na)dajemy im sens, a one 
pragną jedynie spektaklu. Żadna siła nie mogła by ich nawrócić na powagę treści, nawet na powagę kodu" [Baudrillard 2006: 15-16]. Argument autora o zanurzeniu się mas społecznych w konsumpcyjnym zatraceniu sensów, funkcjonujących w spektaklu symulacji znaków i stereotypów, jako gry obrazowych desygnatów („,symulakrów”) wyobrażonych doświadczeń „milczącej większości”, prowadzi go do tezy o roztopieniu się sfery politycznej w sferze społecznej.

Baudrillard uważa, że media, ogłaszając wyniki badania opinii społecznej i konsultacji pochodzące z instytucji przedstawicielskich, budują tautologiczne odpowiedzi na temat głosu lub woli politycznej mas. Masy są dziś spontanicznie i językowo pozapolityczne, bowiem ,nie dokonują wyborów, nie wytwarzają różnic, zachowują fascynację medium, którą przedkładają nad krytyczne wymogi przekazu” - następuje więc „unieszkodliwianie przekazu na korzyść przekaźnika, neutralizowanie idei na korzyść idola, paraliżowanie prawdy na rzecz symulacji" [Baudrillard 2006: 49-50]. Zdaniem Baudrillarda symulakry, imitując i replikując rzeczywistość, zastępująją na zasadzie swoistego pop-artu lub hiperrealizmu, bo odsyłają odbiorców do pustych w sensy znaków, symbolicznie znaczących same siebie [Baudrillard 2005: 6-7]. Narracje estetyzują banalność zmediatyzowanych obrazów, które stanowią iluzję odzwierciedlania rzeczywistości w dyskursach elit z masami. Klasa polityczna wierzy w wiarygodność własnego przekazu, jedynie zakładając, że jest słuchana jako hipotetyczny „rzecznik” biernych mas [Baudrillard 2006: 51].

Wobec koncepcji Baudrillarda zgłosić można zasadniczą wątpliwość. Dlaczego elity kierują swoje narracje w stronę milczącej, bezpodmiotowo funkcjonującej społecznej masy, jeśli pochłania ona każdą narrację i utrwala swą bierność wobec spektaklu symulacji i symulakrów? Czy masy nie współuczestniczą w tworzeniu treści tego komunikacyjnego spektaklu? W składzie mas społecznych są dziś wykształceni i socjalizujący się w zmediatyzowanej komunikacji konsumenci, którzy mają zdolność reinterpretowania symulacji sensów, a przede wszystkim przeżywają konsekwencje konfliktów owych symulakrów, obecnych w dyskursach polityków. Mamy też polski tygiel narodowo-katolickich wartości, wokół których aktywizowane są spory klasy politycznej, a prawicowy fundamentalizm jest silnie przeżywany przez środowiska społeczne, uznające się za depozytariusza „prawdziwej polskości”. M. Czyżewski po części dostrzega te wątpliwości, jednak za argument wzmacniający stanowisko Baudrillarda uważa uchwycenie nowej społecznej jakości, kryzysowego przesunięcia, wymykania się masowego odbiorcy z pola medialnej debaty. Elity, poszukując masowego odbiorcy, buduja zrytualizowany przekaz zależny od ich „oportunistycznego dopasowywania się do jego stopniowo stabilizujących się i niepodatnych na zmianę oczekiwań, w dużej 
mierze «odpolitycznionych» i nastawionych na konsumpcję «medialnej papki»»" [Czyżewski 2010b: 64].

Sama rytualizacja komunikacji elit i mas nie musi oznaczać unieważnienia reakcji jej uczestników na symboliczne kody i manipulacyjne przekazy. Rytualizm politycznej komunikacji wynika po części z cech ponowoczesności, w której-jak pisze Artur Laska - „choć pluralizm światopoglądów wyraźnie rozszerzył pole widzenia, tworzył jednocześnie wrażenie chaosu" [Laska 2006: 39]. Elity symboliczne w kulturze postmodernizmu przestały spierać się o rozumienie świata, a pragmatyczni politycy tworzą swoje narracje zgodnie z odruchami moralnymi i nawykami myślowymi mas społecznych. Ale oni sami często z tych mas także się wywodzą. Utrzymując swą instytucjonalną pozycję, upowszechniają swoiste „technokratyczne spłaszczenie” sensów i arbitralne symulakry wyobrażonych zagrożeń tylko po to, aby zdobyć i utrzymać władzę państwową.

\section{OPINIA PUBLICZNA - OD STATUSOWEJ DEMOKRACJI DO SPOLECZEŃSTWA SPEKTAKLU}

Klasyczna koncepcja obywatelskiej opinii publicznej oparta była na założeniu, że to na mass media demokratyczny system scedował obserwowanie społeczeństwa i aktywizowanie ośrodków politycznych oraz instytucjonalnych autorytetów do deliberowania nad problemami istotnymi dla życia publicznego [Lewiński 2007: 325]. Demokratyczna deliberacja, krystalizująca ważność przekonań zbiorowych za pośrednictwem medialnych oraz politycznych zbiorników opinii [według modelu Karla W. Deutscha, 1968], wymagała uwagi dla intelektualnego głosu profesjonalnych publicystów i niezależnych ekspertów jako instytucjonalnych moderatorów poglądów elit społecznych, którzy - jak wskazywał Giovanni Sartori [1994: 123] - kształtowali poczucie wspólnoty przekonań ludzi z różnych grup odniesienia.

W zachodnich społeczeństwach konsumpcyjnych drugiej połowy XX wieku dominowały segmenty nowych klas średnich, powiązane symboliczną ideą obywatelskiej wspólnoty z klasą wyższą i elitami politycznymi. Klasy panujące politycznie zyskiwały oparcie społeczne w opinii publicznej, wykorzystując mechanizmy „milczącej większości”, które scharakteryzowała Elisabeth Noelle-Neumann. W jej teorii opinia publiczna to ,zmediatyzowana kontrola poglądów prezentowanych jako dominujące przekonania społeczne”, wyrażające ,porozumienie członków wspólnoty w sprawie związanej z afektem, czyli z wartościowaniem respektowanym zarówno przez jednostkę, jak i przez władzę co najmniej na zasadzie kompromisu w publicznie widocznych zachowaniach, pod groźbą 
sankcji odrzucenia lub upadku" [2004: 198]. Teoria ta mówi o uruchomieniu efektu ,spirali milczenia”, która utrudnia racjonalne debatowanie nad adekwatnością publicznych przekazów wobec rzeczywistości. To prawa psychologii społecznej powoduja, że poglądy preparowane oraz propagowane jako powszechnie podzielane w danej społeczności, aktywizując lęk mniejszości przed izolacją lub krytyką i ośmieszaniem za „,ignorancję”, zwiększają szeregi ich oportunistycznych zwolenników. Inny mechanizm to efekt powstający w „twardym jądrze” dominujących opinii, których zwolennicy zanurzeni są w stereotypowych symulacjach i kodach poznawczych. Stają się oni z czasem niezdolni do argumentacji, bo nie spotykają w swoim kręgu społecznym nikogo, kto wyrażałby odmienne zdanie i wymagał uzasadniania wygłaszanych opinii w ich wspólnocie komunikacyjnej [Noelle-Neumann 2004: 115, 191].

Zanik dyskursu politycznego w mass mediach był podstawą analiz Jürgena Habermasa poświęconych historii powstania i upadku sfery publicznej w rozwoju zachodnioeuropejskich państw narodowych. Omówiona w pracy pt. Strukturalne przeobrażenia sfery publicznej tradycja funkcjonowania publiczności określona jako mieszczańsko-obywatelska sfera publiczna zakładała permanentne rezonowanie zaangażowanych obywateli w sferze prywatnej z przekazami mediów oraz środowiskowe kształtowanie politycznych przekonań w „swobodnej i racjonalnej dyskusji”" [Habermas 2007: 95-101]. Habermas był świadom ograniczeń sprawności i reprezentatywności takiego modelu obywatelskiej deliberacji. Wskazywał między innymi na determinowanie publicznych przekonań przez dominację autorytetu mężczyzn, członków elit biznesu i wykształcenia, wpływ klasowych interesów i ideologicznych przekonań na krytykę panującej władzy. Mieszczańsko-obywatelska sfera publiczna w gruncie rzeczy była formą dyskursu burżuazyjnej publiczności, zorientowanej na liberalno-mieszczańskie wartości i powstrzymującej roszczenia władcze absolutystycznego państwa. Habermas, opisując procesy rozpadu sfery publicznej w późnym kapitalizmie, określa proceduralne demokracje jako odwołujące się do nie-publicznej sfery publicznej, czyli form deliberacji zdegradowanej [Jaskólski 2010: 81-86].

Przestrzeń debaty publicznej redukuje nie tylko komercjalizacja opinii publicznej i medialna manipulacja wrażeniami biernej politycznie publiczności. Równocześnie postępuje rozrost funkcji zarządczych państwa i technokratycznych procedur konsultowania się instytucji administracyjnych z organizacjami stowarzyszającymi grupy interesariuszy (dziś zwanych NGO). Powoduje to - jak pisze Paweł Dybel - „«urządzanie» szeregu sfer społecznego życia poprzez użycie różnego rodzaju technik dyscyplinujących i kontrolnych - i w ten sposób 
umacnianie własnej dominacji i władzy nad społeczeństwem” [Dybel 2015: 111]. To rozszerzenie sfer zarządzania publicznego i zobowiązań obywateli wobec państwa oraz interesów oligopoli, komercjalizujących przemysł medialny, Habermas określa jako refeudalizację sfery publicznej [Habermas 2007: 265-278, 320-332]. W konsekwencji tych strukturalnych przemian upada rola polityczności w życiu społeczeństw socjalnego i konsumenckiego dobrobytu.

Praktyki budowania konsensusu opinii publicznej - w warunkach komunikacyjnej i strukturalnej przewagi władzy politycznej nad zdekomponowanymi segmentami masowej publiczności - są dzisiaj proceduralnymi dyskursami stron, jako interesariuszy. Dominacja nie-publicznej sfery komercyjnych interesów oraz klientelizm właścicieli mass mediów sprzyja sięganiu po narzędzia marketingowego kreowania autorytetu mandatariuszy partyjnych. Ale także prowadzi do szybkiego zużywania ich koniunkturalnej retoryki i wizerunków. W krajach proceduralnej demokracji konkurujące ze sobą modele państwa dobrobytu: socjaldemokratyczny, liberalny i konserwatywny, stanowią formy przetargu w zarządzaniu konfliktami społecznymi w określonym cyklu rządzenia [Markowski 2014: 61-65]. Przetarg ten na każdym poziomie komunikacji politycznej związany jest ze zjawiskiem określanym przez Gary C. Woodwarda jako korupcja dyskursu publicznego. Zjawisko to obejmuje takie działania, jak: celowe wprowadzanie przez nadawców do mediów informacji fałszywych, nadużywanie terminologii, zamiana symbolicznego znaczenia pojęć, mistyfikacja co do intencji i interpretacji przebiegu zdarzeń, a nawet formułowanie gróźb i wywieranie przymusu na odbiorców w zakresie interpretowania treści [Woodward 1998: 110-114].

Konsekwencje procesu erozji sfery publicznej pogłębia Richard Sennett. W książce Upadek człowieka publicznego dowodzi, że współczesna nierównowaga - skupienie obywateli na życiu prywatnym i redukcja więzi ze sferą publiczną, czynią z człowieka publicznego jedynie aktora prezentującego społeczne emocje [Sennett 2009: 179-181]. Nowoczesna komunikacja polityczna, oparta na ekspansji elektronicznych mediów, prowadzi zdaniem Sennetta do kresu samej idei życia publicznego. Zwiększając zasób wiedzy jednych grup społecznych o drugich, nowe media niwelują potrzeby: prawdziwego kontaktu z innymi, publicznego doświadczania społecznej różnorodności, dyskutowania różnic i ich politycznego znaczenia na polu prywatnym. Polityk w medialnych wystąpieniach unika zgłębiania programowych sprzeczności; koncentruje się na marketingowym wizerunku własnej osoby, na prezentowaniu telewizyjnej charyzmy osobowości zakorzenionej w sferze wyglądu, życiowych doświadczeń, prywatnych zainteresowań i ekspresyjnych zdolności do odwracania uwagi od 
krytyki ze strony oponentów. Tak funkcjonujące mass media hamują zdolność ludzi do przełożenia tego, co wiedzą, na polityczne działania [Sennett 2009: 251, 457-458].

Dla polityków jako publicznych performerów kluczem do sukcesu w pozyskiwaniu uwagi publiczności złożonej z drobnomieszczańskich konsumentów i ludzi obciążonych kosztami transformacji jest „podżeganie społeczeństwa do ataków na Estabilishment, Władzę, Stary Porządek”. Wykorzystanie takiej perswazji łączy się z socjalnym populizmem oraz resentymentem wobec uprzywilejowanych i sterujących niesprawiedliwym systemem. Populizm, podobnie jak resentyment, posługuje się argumentacją spiskową, wskazując ukryte siły odpowiadające za wykorzystywanie mas społecznych i operując pół prawdami, a pół złudzeniami [Sennett 2006: 448, 449].

W dyskursach publicznych masy społeczne pobudzane są do zachowań reaktywnych. Zainteresowanie publiczności polityką nie jest motywowane aktywnością obywatelska, lecz konsumowaniem jej spektakli, wyrażających grę społecznych namiętności i konfrontacyjnych komunikatów. Te zaś odnoszone są do kontekstu osobistych doświadczeń obywateli, jako osób nie politycznie i ideowo, lecz kulturowo i emocjonalnie ulokowanych wobec ekspresji symbolicznych form dyskursu. Wartość reakcji społecznej na symulakry rzeczywistości, jakimi operują adwersarze dyskursu, tkwi również w celowym wywołaniu świadomości iluzji lub rytualizmu sporu politycznego. Dyskurs polityków skierowany jest na stymulowanie bierności obywateli wobec ich manipulacyjnych zabiegów, wykorzystujących propagandowo dominujące medialnie lub kulturowo przekonania. Głównym celem nowych mass mediów ,jest przyciagniecie dużej publiczności a nie dbanie o jej rozwój", w związku z czym wykorzystują one popkulturowe imperatywy sensacji, skupiając swoją uwagę na życiu celebrytów i naśladowczej rywalizacji o konsumencki sukces [Frank, Cook 2007: 259]. Spektakl medialny, oferowany przez cyberkomunikację, wiążą z mobilizacją zasobów ludzkich do współdziałania z elitami świata korporacji i liderami politycznych konstelacji, organizującymi scenariusze zarządzania rynkami zwycięzców, które kumulują dysponowanie globalnymi kapitałami w rękach jednego procenta [Stiglitz 2015: 227-241].

Kultura imitacyjnego konsumpcjonizmu, który prowadzi do rytualizmu rywalizacji oraz poczucia kolektywnego chaosu jest dobrze identyfikowana w teorii kryzysu mimetycznego przez René Girarda. Kryzys mimetyczny wynika z powielania pożądliwości społecznej wobec obiektu rywalizacji w naśladowczych działaniach, które zacierają granice ideowych norm uzasadniających prawo rywali do dysponowania obiektem pożądania. Jest to model uniwersalny, antro- 
pologiczny, wyjaśniający, że rywale wraz z natężeniem sporów motywowanych pożądaniem władzy stają się coraz bardziej do siebie podobnymi sobowtórami pragnień dominacji nad oponentami. Kluczowy efekt mimetycznej rywalizacji wynika z zaostrzania kulturowych roszczeń przez piętnowanie rywali, co rodzi zaraźliwe społecznie postawy kreowania i wykluczania „kozłów ofiarnych” jako winnych chaosu lub zagrożeń dla całej wspólnoty [Girard 2006: 61-63; 1987: 50-51]. To właśnie taka dynamika mimetycznego kryzysu w kulturze postnowoczesności jest podstawą eksploatowania kolektywnych resentymentów w wirtualnej komunikacji społecznej i wzmacnia negatywne ukierunkowanie przekazów pop-polityki.

\section{WIRTUALIZACJA POP-POLITYKI W FAZIE PREKARYZACJI}

Rozpad opinii publicznej na konsumenckie segmenty sympatyków dyskursów pop-polityki wiąże się z ekspansją technik cyfrowego formatowania przyzwyczajeń i aktywizowania upodobań klientów za pomocą wirtualnej kontroli nad ich konsumpcją [Stiglitz 2015: 60-61]. Procedury cyfrowego identyfikowania i stymulowania postaw konsumenckich przenosi się na wirtualne formatowanie i aktywizowanie sympatii politycznych uczestników forów opinii obywatelskich. Oddziaływanie takie ułatwia postępujące ,rozrzedzanie” demokracji, związane ze sporadycznym udziałem młodych ludzi w wyborach i rosnącym segmentem elektoratu nieufnego, znudzonego oraz apatycznego, co sprzyja sukcesowi ugrupowań o niskim poparciu wyborczym [Standing 2014: 291-293]. Guy Standing wskazuje, że wyłaniająca się w turbokapitalizmie nowa klasa prekarna, to heterogeniczny społecznie i kulturowo segment struktury społecznej, doświadczający skutków neoliberalizmu w postaci utraty kontroli nad warunkami swej pracy i zabezpieczeniami socjalnymi w czasowym zatrudnieniu. Jest to zbiorowość wrażliwa na język wyrażający uczucia lęku, nostalgii za „złotą erą” minionego sukcesu, alienację z godności, moralne oburzenie na sprawców zagrożeń dla jej wolności, ekonomicznego i ekologicznego bezpieczeństwa [Standing 2014: 49, 305-309]. Dodać trzeba, że prekariusze są wykształceni, aktywni w przestrzeni wirtualnej komunikacji, a czasem zatrudniani do obsługi mediów cyfrowych, stanowią więc łatwą do zagospodarowywania publiczność pop-polityki.

Publiczność tę cechuje niechęć do polityków, rezygnowanie z odbioru programów politycznych, a nawet posiadania telewizji. Badania pokazują że w socjalizacji młodzieży brakuje kształtowania postawy szacunku dla autorytetów społecznych, religijnych i akademickich. Tylko nieliczni młodzi ludzie wchodzący do polityki uznająjakieś autorytety polityczne [Przybylski 2013: 69-70]. Sprawia 
to po części, że wirtualna pop-polityka, budując swoje dyskursy na wrażeniach i sympatiach, zdecydowanie wykracza poza zracjonalizowaną argumentację. Uwodzenie elektoratów odbywa się na poziomie wspólnoty resentymentów i kreowania atrakcyjnych wizualnie oraz środowiskowo kodów kulturowej tożsamości.

Eksploatowanie wirtualnej przestrzeni dla agresywnego dyskursu pozwala politykom aktywizować szczególnie gęste emocjonalnie narzędzia modelowania sympatii lub antypatii do różnych społeczności i ruchów obywatelskich. Cechy nowej usieciowionej komunikacji politycznej nie są same w sobie zagrożeniem dla demokratycznego dyskursu [Koza 2015: 239, 240]. Kluczowe jest to, że prowadzenie gier komunikacyjnych za pomocą serwisów społecznościowych bywa profilowane przez anonimowe grupy nadawców, których podmiotowość polityczna nie jest czytelna. Orientacja na zyski z internetowej ekonomii ułatwia im instrumentalną manipulację treściami przekazu. Problem wynika z dominacji egoistycznego i rywalizacyjnego nastawienia uczestników dyskursów, których nakłania się do rezygnacji z obywatelskich potrzeb i udziału w oporze wobec politycznych mocodawców manipulacyjnego przekazu. A takim formom oddziaływania nowych mediów sprzyja regres reguł profesjonalnego dziennikarstwa oraz etyki zespołów redagujących zza kulis globalną cyberkomunikację z jej popkulturową sensacyjnością, pełną komercyjnie i politycznie manipulowanych obrazów [Jastrzębski 2009: 23-27, 129-142].

Pop-polityka kieruje uwagę adresatów na sensacyjne i popularne obrazowanie cech postaci sceny publicznej, bez zbytniej troski o weryfikowanie przywoływanych informacji. W pop-polityce sympatie obywateli są aktywizowane głównie za pomocą emocjonalno-roszczeniowych i godnościowych narracji, łączących ich symbolicznie, a nie intelektualnie z określoną orientacją polityczną. Profilowana jest również prawda, jako środek propagandowej ekspresji aktorów politycznych. Nowy status narracyjnych form niedialogicznego komunikowania w postnowoczesnej polityce zaowocował między innymi takimi kategoriami, jak „fake-news” czy „postprawda”, które niedawno umieszczono w oksfordzkim słowniku języka angielskiego ${ }^{7}$. Ich epistemologiczną siłą jest organizowanie wyobrażeń zbiorowych poprzez wiązanie doświadczeń „zwykłych ludzi” z siatką znaczeń kulturowych i miejsc materializujących historyczne symbole kolektywnego losu wspólnoty politycznej, etnicznej czy religijnej. Lech Nijakowski opisuje te

7 Oxford English Dictionary uznał pojęcie postprawdy za słowo 2016 roku, wskazując, że ,odnosi się lub oznacza okoliczności, w których obiektywne fakty są mniej wpływowe w kształtowaniu opinii publicznej niż odwołanie się do emocji i osobistych przekonan” [cyt. za „Rzeczpospolita”, wydanie z dn. 30.01.2017. http://www.rp.pl/Spoleczenstwo/161119202-Oxford-Dictionariesuznaly-post-prawde-za-slowo-2016-roku.html [dostęp: 25.08.2018]. 
praktyki narracyjne jako ustanawianie domen symbolicznych, które buduja poczucie wspólnoty wartości wokół kulturowego „wyobrażonego podobieństwa”, oddzielającego „swoich” od „obcych” [Nijakowski 2006: 100-111].

Cyfrowe narzędzia marketingowego bootowania i trollowania politycznych wizerunków rywali okazały się wysoce przydatne w wywoływaniu negatywnych skojarzeń blokujących potencjał polityczny i wyborcze szanse wielu kandydatów. Dlatego pop-polityka uprawiana w Internecie zyskała jeszcze silniejsze instrumenty ukrytego wpływu na sympatie i gusta polityczne uczestników społecznościowych forów. Jednym z nich jest ,efekt Google”, oznaczający automatyczne pozycjonowanie preferencji uczestników, którzy otrzymują z Sieci opinie o danym zjawisku, afirmujące ich zapatrywania. Inne opinie są jedynie echem z „silosów” lub „baniek” informacyjnych adresowanych do profili odbiorców o odmiennych orientacjach kulturowych i światopoglądowych. Elektronicznie komunikujące się społeczności stanowią swoiste stada, opasane wiązką elektronicznych przekazów, odrębnie pozycjonujących wspólnotę swoich opinii i symbolicznych kodów obywatelskiej tożsamości.

Szczególnym i specyficznie ważnym narzędziem cyfrowej kolonizacji opinii obywatelskich okazało się korzystanie z korporacyjnych algorytmów marketingowej analizy big data. Opracowane jako narzędzia komercyjne są stosowane do ukrytego profilowania orientacji politycznych użytkowników mediów społecznościowych. Służą one do śledzenia ich opinii i aktywizowania negatywnymi przekazami, w celu dezorientacji postaw wobec liderów politycznych lub demobilizacji do głosowania na określone ugrupowania. Opisywane przez publicystów techniki czerpania danych z mediów społecznościowych oraz psychologicznego portretowania ich użytkowników zostały opracowane i komercyjnie oferowane sztabom wyborczym przez zespół Cambridge Analityca [Ćwiklak 2018], który pozyskał dostęp do prywatnych danych z profili 87 milionów użytkowników Facebooka. Wybuchła głośna afera z poważnymi biznesowymi konsekwencjami dla giełdowej wartości tego giganta mediów sieciowych. Jednak wpływ marketingu sieciowego na uprawianie demokratycznej i otwartej polityki jest już nieodwracalny. Propagują go nowe poradniki cyfrowego public relations w polityce i biznesie [Meerman 2017].

Pop-polityka zyskała nowe ukryte narzędzia kreowania nastrojów wybranych segmentów aktywnego elektoratu. $Z$ tego właśnie względu określenie jej terminem pop-politics wyprowadzam z praktyk political orientation profiling, sięgających po kolektywne i prywatne domeny sieciowe dla kreowania symbolicznego przekazu i kolonizowania sympatii ich użytkowników. Takie narzędzia oddziaływania wykorzystują również służby specjalne państw. Ostatnie kampanie 
wyborcze w USA, Francji, Czechach, a także w innych krajach, w tym w Polsce, były poddawane oddziaływaniu rosyjskich agend sieciowego wpływu.

Praktyki zakulisowego, ukrytego stymulowania sympatii/antypatii elektoratów kształtują hybrydowość demokratycznej debaty politycznej poprzez wywołanie efektu cyfrowego domina. Dyskurs obywatelski występuje w różnych segmentach usieciowionej publiczności, jako emocjonalno-identyfikacyjny przekaz lajków i tweetów. W ich następstwie status poznawczy ścierających się publicznie stanowisk ma poważne pęknięcia wynikające z silosowania przekonań opinii publicznej, przesuwania się otwartego dialogu autorytetów na poziom polemiki blogerów; argumentacje ideowe stają się formą gry tożsamości i rytualnej konfrontacji wspólnot symbolicznych, widoczna jest niechęć do dyskutowania praw mniejszości światopoglądowych lub obyczajowych, kreowania fałszywych narracji i pozornych uzasadnień dla realizacji politycznych interesów własnych wspólnot kosztem praw opozycyjnych sił społecznych. Spektakl pop-polityki toczy się przed zdekomponowanym klasowo i rozwarstwionym ekonomicznie audytorium, które wyłania z siebie słabe obywatelskie struktury, będące swoistymi klientami i agendami sieci politycznych. Dążeniem aktorów politycznych staje się zdobycie i zatrzymanie środków rządzenia technikami dezawuowania legitymizacji do ich posiadania przez rywali z innych ugrupowań, piętnowanych instrumentalnie i koniunkturalnie, jako zagrażających poczuciu sprawiedliwości, zasadom kulturowym lub wolności obywateli.

\section{POLSKI KONSERWATYZM JAKO WERSJA NARODOWEJ POP-POLITYKI}

Od wielu już lat badacze języka polskiej polityki wskazują na jego systematyczne perswazyjne profilowanie [Język IV. RP 2010]. Politycy z dużą zręcznością uwzględniają: skłonności aksjologiczne grup społecznych, których uczestnicy chcą wierzyć w to, w co chcą wierzyć; afirmują działania zgodne z typowymi postawami adresatów swoich opinii; wykorzystują reguły społecznej uwagi i to że ludzie reagują stereotypowo na stereotypowe bodźce oraz emocjonalnie na ukryte znaczenia słów; łatwo uznają te idee, do których mają pozytywny stosunek; ulegają zbiorowym sugestiom, a swoje zachowania uznają zwykle za słuszne, logiczne i rozsądne [Banasik 2002: 25].

To jak uwodzą swoje elektoraty politycy prawicy, opisuje Laura Polkowska, systematycznie analizując ich przemówienia sejmowe. Wykazuje, że „w tekstach

8 Por. np. https://natemat.pl/210925,platna-prawica-jak-trolle-konserwatystow-i-putinatrzesa-polskim-internetem [dostęp: 25.08.2018]. 
prawicowych przemówień sejmowych zdecydowanie przeważa argumentacja emocjonalna, natomiast najrzadziej wykorzystywane bywają argumenty racjonalne, które pojawiają się niemal wyłącznie w wypowiedziach dotyczących spraw stricte prawniczych" [Polkowska 2015: 145]. Podkreśla, że erystyczne, napastliwe argumenty emocjonalne są znacznie częściej stosowane niż racjonalne argumenty moralne. Służą one bowiem głównie piętnowaniu adwersarzy i przerzucaniu na nich winy za język agresji [Polkowska 2015: 145-146]. Charakteryzując praktyki perswazyjne partii Prawo i Sprawiedliwość, Ludwik Habuda pisze: „Są to zabiegi, które wyborców nie upodmiotowiają, lecz uwodzą, ich skuteczność nie polega na uczynieniu z widzów intelektualnych partnerów, lecz na pociągnięciu ich za sobą [...] [jako - AB] obserwującej występy gawiedzi.[...] W takiej walce, jeśli sięga się do prawdy, to tylko wówczas i o tyle, o ile przez choćby jedną z walczących stron sięganie takie uważane jest za korzystne dla niej" [Habuda 2010: 195].

Pop-polityka ma również swoją celową - chociaż instrumentalną z założenia - formę kreowania sondażowego stanu świadomości obywateli, profiluje ponadto cechy ich pamięci historycznej. Moderuje ją przez transformowanie lub intencjonalne tworzenie treści ukazujących pozytywny wizerunek własnej grupy i legitymizujących jej roszczenia wobec wybranych wydarzeń i bohaterów przeszłości. Jacek Raciborski wskazuje na takie agregowanie preferencji osób badanych za pomocą sondaży opinii obywatelskich, które służą równocześnie kształtowaniu preferencji obywateli informowanych o opiniach ludu [Raciborski 2011: 279].

Polska pop-polityka w pełni świadomie organizuje konfrontacyjne domeny symboliczne. Znaczenie traci inteligencki dyskurs, ponieważ rywalizujące strony czerpią energię z antyinteligenckich strategii komunikacyjnych [Nowicka-Fronczak 2018: 79-96]. Fakt, iż odbiorcy są świadomi ideologicznej manipulacji dla celów politycznych, nie zmniejsza jej profilującego oddziaływania i sprzyja symetrii w rozwoju tych praktyk. Pierwsze pozytywne doświadczenia skuteczności marketingu sieciowego w profilowaniu wizerunku kandydata PO pochodzą z internetowej kampanii Rafała Trzaskowskiego do Europarlamentu w 2009 roku. Zauważono wówczas atuty budowania narracji politycznej wykorzystującej więzi społecznościowe i zwrotny efekt poznawania emocji i oczekiwań uczestników aktywizowanych forów [Leszczuk-Fiedziukiewicz 2011: 38-39, 51]. Fora in-ternetowe stały się dla polskich partii atrakcyjnymi kanałami komunikacji sieciowej, zwiększającymi skuteczność podążania za nastrojami elektoratu zanurzonego w medium kultury popularnej. W ostatnich kampaniach wyborczych Prawo i Sprawiedliwość zdominowało dyskursy mediów społecznościowych, wykorzystując przede wszystkim hejt wobec imigrantów, „brudnych uchodź- 
ców”, „lewactwa”, „antypolskości” polityki rządów PO. Jednak już jako partia rządząca PiS także podlega ostrym sieciowym atakom za autorytaryzm, ustawy niszczące niezależność sądownictwa i naruszanie konstytucji ${ }^{9}$. Obie strony zwalczają swój hejt, odwołując się również do internetowych memów i blogerskich narracji [http://niezalezna.pl/67751-internet-smieje-sie-z-hejterow-platformyobywatelskiej-obejrzyj-memy-i-wideo]. Badania Roberta Gowry z 2017 roku wskazują, że w Polsce, w porównaniu z innymi państwami, intensywne jest zjawisko bootowania tożsamości na politycznych forach społecznościowych, gdzie 33\% nadawców ma cechy cyfrowych algorytmów, nie licząc spersonalizowanych kont rozsyłających perswazyjne „fake newsy”. Dwukrotnie intensywniej generowane są treści bootów ze stron prawicowych (sympatyków PiS) niż lewicowych (PO, KOD, Obywatele RP). Takie nasycanie dyskursu publicznego nieprawdziwymi przekazami z kont Facebooka, Tweetera i sieciowych blogów może spowodować, że nie będzie szans weryfikowania wiarygodności zarzutów replikowanych przez cyfrowych trolli [Gowra 2017: 24-26]. A w gruncie rzeczy samozwańcze lub opłacane internetowe „wyrocznie”, atakując przeciwników za manipulacje, same manipulują, nadużywając retorycznej agresji [https://natemat. pl/160039,samozwancze-internetowe-wyrocznie-jak-prawicowe-strony-obnazaj a-manipulacje-same-manipulujac].

Retencja polemicznych figur i inwektyw sprawia, że te popularne w wirtualnej publicystyce są przenoszone na areny parlamentarne i wykorzystywane do ataków na autorytety zakorzenione w liberalnych i lewicowych mediach oraz inteligenckich środowiskach zawodowych, przez prawicowe ośrodki nazywanych „łże-elitami”, „resortowymi dziećmi”, „mafiami w togach” itd. Do narracyjnych technik pop-polityki aktywizujących potoczne myślenie obywatelskie należy według Laury Polkowskiej stosowanie słów-zaklęć i słów-etykietek. W prawicowo-konserwatywnej narracji zaklęcia eksponują pozytywne wspólnotowe wartości (naród, polskość, suwerenność, niepodległość, wolność, sprawiedliwość, rodzina, ziemia, ojczyzna, katolickie tradycje), a słowa-etykietki (komunizm, globalizm, federalizm, liberalizm, feminizm, ateizm, nacjonalizm, faszyzm, autorytaryzm) służą do profilowania dystansu wobec aktorów obciążanych przez kojarzone z nimi negatywne wartości [Polkowska 2015: 42-70].

Perswazyjna wybiórczość ocen i arbitralność form wykluczania imituje podążanie za gustami publiczności forów sieciowych, wynika jednak ze świadomego dążenia do panowania nad nastrojami społecznymi. Budowanie

9 Por. https://www.gosc.pl/doc/2777841.Internet-w-Polsce-jest-prawicowy oraz http://www. gazetakrakowska.pl/artykul/8866523,prawo-i-sprawiedliwosc-kroluje-w-polskim-interneciepomaga-w-tym-zdyscyplinowana-armia-trolli,id,t.html. [dostęp: 25.08.2018]. 
perswazji politycznej odwołującej się do kodów kultury popularnej w polskiej polityce przybrało formy dyskursu pamięci historycznych krzywd. W tym celu konserwatywne siły polityczne powołały Instytut Pamięci Narodowej, który realizuje „politykę historyczną” jako oficjalną koncepcję profilowania narodowej świadomości polskiego społeczeństwa. Rząd PiS, posługując się publicznymi mediami, programami informacyjnymi i sieciami patriotycznych organizacji, buduje symulakry z autostereotypów „dumnego narodu” [Migalski 2017]. Jawna perswazja historyczna władzy politycznej, zagospodarowująca domeny symboliczne i profilująca orientacje społeczno-kulturowe elektoratów, nie jest zaproszeniem do obywatelskiej debaty nad tradycjami politycznymi. Różnicuje poziom dumy narodowej i profiluje oceny historii własnego państwa, lecz - jak twierdzi Krystyna Skarżyńska - sprzyja raczej biernemu nacjonalizmowi Polaków, gdyż wzmacnia retencyjnie postawy ekskluzywności etniczno-kulturowej, a nawet ksenofobii. Nie przekłada się bezpośrednio na poparcie określonych opcji politycznych, ale raczej buduje poczucie konwencjonalnej wspólnotowości [Skarżyńska 2011: 289-294]. Lech Nijakowski wskazuje, że wiele tych politycznych zabiegów profilowania obywatelskiej wspólnoty ,ukrytych jest za panowaniem symbolicznym, które ludziom jawi się jako panowanie jedynie nad rzeczami” [2006: 109]. Korelatami tych praktyk są budowane lub likwidowane pomniki, nazwy ulic, tworzone muzea, instytucje i programy organizujące grupy gotowe do pielęgnowania modelowanych politycznie tożsamości.

Agresywny dyskurs rządzącej dziś w Polsce prawicowej elity władzy ma na celu destrukcję politycznego znaczenia oponentów sytuowanych w nurcie postnowoczesnego liberalizmu oraz postkomunistycznej lewicy. Deklarowanym celem jest obrona i odbudowa konserwatywnych wartości społecznych. Temu przekazowi opozycja przeciwstawia krytykę nadużyć i manipulacji rządów PiS [por. Raport gegaczy 2016].

Polityczna narracja prawicy ma na celu skupienie jej zwolenników w symbolicznej domenie historycznej narodowej wspólnoty, budowanej poprzez afirmowanie katolickich tradycji polskiego narodu (stanowiących pewne ,patriotyczne minimum”). Prowadząc debatę na temat „wyłaniającego się archipelagu polskości" ", prawica pozycjonuje tym samym swoją wartość jako depozytariusza całej wspólnoty moralnej. Ludziom doznającym poczucia aksjologicznego lęku, lub też wykluczeń z korzyści przez narzucone politycznie „układy”, obiecuje przywrócenie społecznej sprawiedliwości przez silną władzę kierującą się na-

10 https://wpolityce.pl/polityka/340364-prof-glinski-na-kongresie-pwp-bez-archipelagu-pol skosci-nie-byloby-w-polsce-demokracji [dostęp: 14.11.2018]. 
rodowym interesem. Taka konserwatywna polityka oferuje swym zwolennikom paternalistyczne schronienie. I to jest najważniejsza dźwignia poppolitycznego profilowania dyskursu - kontrolowanie emocji mas obywatelskich poprzez rytuały komunikowania się elity władzy ze zwolennikami pojmowania porządku publicznego jako odgórnie budowanego, wspólnotowego ładu. Konserwatywna, moralnie prokatolicka polityka dyskursywnie nie godzi się na presję multikulturowych liberalnych wzorców i interesów ponadnarodowych struktur gospodarczych. Z ideologiczną żarliwością konfrontuje się z transferem liberalnych norm obyczajowych, z krytyką ciemnych kart polskiej historii i nauczania Kościoła katolickiego. Sięganie po niedialogiczne środki rywalizacji politycznej czerpie energię z resentymentów mas i lęków zbiorowości, zachęcanych do piętnowania oponentów z powodu różnic aksjologicznych i tożsamościowych. Tym samym symbolicznie redukuje nie tylko pluralizm kulturowo-społeczny, ale także obywatelskie wzorce demokratycznego kontrolowania działań władzy, przez co wzmacnia autokratyzm decydentów w praktykach rządzenia. To w tym sensie dyskurs polskiej prawicy powraca do tradycji senioralno-paternalistycznej, łącząc wspólnotowo-religijną więzią rządzące elity i wyobrażony podmiot polityczny - suwerenny naród. Symbolicznym kodem paternalistycznej moralności jest hasło „Bóg, honor, ojczyzna”.

W tradycjonalnym porządku legitymizacji elity władzy paternalizm odwołuje się do charyzmatycznych źródeł autorytetu lidera-seniora, decydującego pozaformalnie o godności członków rządzącej ekipy i aspirantów do pełnienia publicznych urzędów. Taki model dyskursu wtłacza społeczeństwo obywatelskie w kod etnicznej polityki, aktywizując patriotyczny związek ludu, pana i plebana. Dla przeciwników owej struktury rządzenia w Polsce oznacza on natomiast prawicowy neoautorytaryzm lub infantylną dyktaturę ${ }^{11}$.

\section{WNIOSKI}

Analiza mechanizmów sieciowego profilowania sympatii politycznych i symbolicznej konfrontacji dyskursów potwierdza wzrost ich zasięgu i znaczenia dla dzisiejszej komunikacji politycznej.

W zakresie teoretycznym pop-polityka jest hipotezą użyteczną, ponieważ wskazuje, jak duże są możliwości rozwoju nie-politycznej sfery publicznej dzięki

11 Taką tezę sformułowała w publicystycznej wypowiedzi profesor Jadwiga Staniszkis - por. http://wiadomosci.dziennik.pl/opinie/artykuly/509159,jadwiga-staniszkis-o-trybunale-konstytucyjn ym-rzadzie-pis-i-andrzeju-dudzie.html?utm_source=powiazane-w-art\&utm_medium=link [dostęp: 25.08.2018]. 
angażowaniu wirtualnych społeczności w dyskurs nad popularnością i wizerunkami liderów oraz ugrupowań politycznych.

Rytualizm komunikacyjny oparty na emocjonalnej agresji i wykluczaniu rywali z preferowanych przez siebie wspólnot symbolicznych nie jest jednak pustą formą różnicowania się lub nawet grą wizerunkami (ich symulakrami - jak chce Baudrillard). Wskazane w pracy sprzężenia strukturalnego rozrzedzania klas średnich przez prekaryzację i oligarchizację, jako skutki neoliberalnej globalizacji, aktywizują społeczne resentymenty oraz imitacyjną rywalizację.

Rytualizacja jest konsekwencją mimetyzmu rywalizacji odrywającej się od ideologicznych zasad; rodząc chaos norm, przechodzi w fazę kryzysu wspólnoty politycznej. Krystalizują się wrogie sobie symbolicznie konfiguracje elit, praktykujące jednak na zasadzie opozycyjności te same polityczne zabiegi budowania więzi z elektoratami. W polskim przypadku kryzys mimetyczy wzmacnia rytualizm w praktykowaniu demokratycznych wartości, bowiem rozpad pokomunistycznej inteligencji na neoliberalne i konserwatywne segmenty krystalizuje definiowanie „kozłów ofiarnych” przez wszystkie strony uczestniczące w grze o zdobycie środków rządzenia państwem.

Ponieważ w sferze publicznej dominuje niedialogiczny system komunikowania, reguły ustanawiania autorytetów opinii mają charakter środowiskowy i paternalistyczny. Zawłaszczanie przestrzeni symbolicznej odbywa się przez wykluczanie rywali z prawa do jej współtworzenia. Paternalistyczna forma prowadzenia dyskursów ukierunkowanych na niszczenie wizerunków i autorytetu rywali politycznych czyni z narzędzi pop-polityki chętnie i cynicznie wykorzystywane medium. Sięgają po nie wszystkie strony polskiego sporu publicznego. Brakuje nam w konsekwencji pola do prowadzenia debaty nad konstruowaniem liberalnego modelu patriotyzmu i otwartego na ponowoczesność konserwatyzmu. Takiej debaty nie zapewni poppolityczny spektakl Obywateli RP jako obrońców Konstytucji.

Dalszego zbadania wymagają szczególnie trzy problemy generowane przez mechanizmy pop-polityki: trwałość profilowania sympatii i antypatii internautów wobec zwalczających się ugrupowań politycznych; wpływ preferencji etycznych na zasięg społeczny totalizującej moralistyki, czyli podatność ideowa obywateli na profilowanie swoich orientacji na wartości publiczne i kody wspólnotowe; skuteczność zakulisowego wpływania przez wrogie sieci profilowania opinii obywatelskich z zagranicy. Jest to poważne zagadnienie z zakresu cyberbezpieczeństwa dyskursu publicznego i odporności całego systemu politycznego na wrogą medialną ingerencję w przebieg kampanii wyborczych. 


\section{BIBLIOGRAFIA}

Abucewicz Monika. 2012. „Postmodernizm z perspektywy krytycznej teorii kultury czyli o dominacji ideologii neoliberalnej i współczesnych mechanizmach kontroli”. Normy, Dewiacje i Kontrola Społeczna 13: 80-104.

Abramowicz Bartosz. 2011. „Koncepcja demokracji deliberacyjnej jako odpowiedź na postulaty usprawnienia demokracji przedstawicielskiej”. Ruch Prawniczy, Ekonomiczny i Socjologiczny LXXIII/4: 215-229.

Adamowicz Tomasz. 2013. „Przyczyny i skutki I fazy kryzysu finansowego lat 2007-2009 w wybranych krajach na świecie". Polityki Europejskie. Finanse i Marketing 9(58): 9-21. Warszawa: Wydawnictwo SGGW.

Armingeon Klaus, Kai Guthmann. 2014. „Democracy in crisis? The declining support for national democracy in European countries, 2007-2011". European Journal of Political Research 53(3): 423-442.

Banasik Aneta. 2002. Jak uwodza politycy. Język marketingu politycznego w kampanii wyborczej '97. Katowice: Wydawnictwo Uniwersytetu Śląskiego.

Castells Manuel. 2013. Władza komunikacji. Warszawa: Wydawnictwo PWN.

Ciołkiewicz Pawel. 2009. „Strukturalne przeobrażenia sfery publicznej według Jürgena Habermasa - koncepcja, krytyka, zastosowania". Media, Kultura, Społeczeństwo 1(4): 175-189.

Ćwilak Dariusz. 2018. „Wyborcza broń masowego rażenia”. Newsweek Polska 14, wydanie $\mathrm{z}$ dnia 26.03-02.04: 4-87.

Czyżewski Marek. 2010a. Trzy rodzaje dyskursu. W: Rytualny chaos. Studium dyskursu publicznego, M. Czyżewski, S. Kowalski, A. Piotrowski (red.), 18-34. Warszawa: Wydawnictwa Akademickie i Profesjonalne.

Czyżewski Marek. 2010b. W stronę teorii dyskursu publicznego. W: Rytualny chaos. Studium dyskursu publicznego, M. Czyżewski, S. Kowalski, A. Piotrowski (red.), 49-117. Warszawa. Wydawnictwa Akademickie i Profesjonalne.

Deutsch Karl W. 1968. The analysis of international relations. New York. Ed. Engelwood Cliffs.

Dybel Pawel. 2015. Dylematy demokracji. Kontekst polski. Kraków: Wydawnictwo Universitas.

Fleischer Michel. 2007. Ogólna teoria komunikacji. Wrocław: Wydawnictwo Uniwersytetu Wrocławskiego.

Gaworski Tomasz. 2011 „Europejska walka z islamskim terroryzmem”. Dialogi Polityczne. 14: 131-147.

Gąciarz Barbara. 2008. Słabości i szanse demokracji w Polsce. Ład społeczny a rozwój demokracji w dobie modernizacji. W: Strukturalne podstawy demokracji, A. Rychard (red.), 83-108. Warszawa. Wydawnictwo IFiS PAN.

Girard René. 1987. Kozioł ofiarny. Łódź: Wydawnictwo Łódzkie.

Girard René. 2006. Poczatki kultury. Kraków. Wydawnictwo Znak.

Gowra Robert.2017. „Computational propaganda in Poland: False amplifiers and the digital public sphere". Working Paper 4: 1-36.

Graszewicz Maurycy. 2011. Polski system polityczny. Semantyki i struktury komunikacji politycznej. Wrocław. Wydawnictwo Uniwersytetu Wrocławskiego.

Habuda Ludwik. 2010. Prawa i Sprawiedliwości Rzeczpospolita Polska. Opole. Wydawnictwo Uniwersytetu Opolskiego. 
Jasiecki Krzysztof. 2008. Integracja z Unią Europejską jako strukturalna determinanta polskiego systemu politycznego. W: Strukturalne podstawy demokracji, A. Rychard (red.), 223-250. Warszawa: Wydawnictwo IFiS PAN.

Jaskułowski Krzysztof. 2010. „Koncepcja sfery publicznej Jurgena Habermasa”. Spotkania Europejskie 3: 69-86. Wrocław.

Jastrzębski Jerzy. 2009. Na rynku wartości. O mediach i etyce dziennikarskiej. Wrocław. Wydawnictwo Uniwersytetu Wrocławskiego.

Jessop Bob. 2008. Kulturowa ekonomia a struktura dyskursu. W: Krytyczna analiza dyskursu. Interdyscyplinarne podejście do komunikacji społecznej, A. Duszak i N. Fairclough (red.), 121-148. Kraków: Wydawnictwo Universitas.

Język IV Rzeczypospolitej. 2010. M. Czerwiński, P. Nowak, R. Przybylska (red.), Wydawnictwo Uniwersytetu Marii Curie-Skłodowskiej. Lublin.

Kampka Agnieszka. 2014. Debata publiczna. Zmiany społecznych norm komunikacji. Warszawa: Wydawnictwo Oficyna Naukowa.

Koza Michal. 2015. „Czy znasz ten mem? Pragmatyka i polityka internetowych wspólnot interpretacyjnych". Teksty Drugie 3: 236-245. Kraków.

Kurczewska Joanna. 2004. Inne niepokoje polskie (zamiast zakończenia). W: Niepokoje polskie, H. Domański, A. Ostrowska, A. Rychard. (red.), 401-448. Warszawa: Wydawnictwo IFiS PAN.

Laska Artur. 2006. Technokratyczne spłaszczenie dyskursu o sprawiedliwości społecznej w sieci polityki globalnej. W: Globalizacja - pomiędzy polityka a ekonomia, D. Karnowska, M. Szatlach (red.), 37-68. Toruń: Wydawnictwo Adam Marszałek.

Lewiński Dominik. 2007. Media i polityka. Interferencyjna koncepcja mediatyzacji. W: Media w Polsce. Pierwsza władza IV RP?, M. Sokołowski (red.), 349-359 Warszawa: Wydawnictwa Akademickie i Profesjonalne.

Leszczuk-Fiedziukiewicz Anna. 2011. „Internet jako narzędzie kreowania wizerunku polityka”. Nowe Media 2: 31-54.

Markowski Radosław. 2004. Populizm a demokracja: ujęcia, dylematy, kontrowersje. W: Populizm a demokracja, R. Markowski (red.), 11-32. Warszawa: Instytut Studiów Politycznych PAN.

Meerman David Scott. 2017. The new rules of marketing \& PR. Hoboken. John Wiley \& Sons,

Matteralt Armand, Matterald Michele. 2001. Teorie komunikacji. Krótkie wprowadzenie. Warszawa: Wydawnictwo Naukowe PWN.

Migalski Marek. 2017. Budowanie narodu. Przypadek Polski w latach 2015-2017. Łódź: Wydawnictwo Liberte!

Nijakowski Lech M. 2006. Domeny symboliczne. Warszawa. Wydawnictwo Naukowe Scholar.

Noelle-Neumann Elisabeth. 2004. Spirala milczenia. Opinia publiczna - nasza skóra społeczna. Poznań: Wydawnictwo Zysk i S-ka.

Nowicka-Fronczak Magdalena. 2018. Antyinteligenckość jako strategia komunikacyjna w debacie publicznej w Polsce. W: Od inteligencji do postinteligencji. Watpliwa hegemonia, P. Kulas, P. Śpiewak (red.), 72-101. Warszawa: Wydawnictwo Scholar.

Piotrowski Andrzej. 2010. Wewnętrzna dynamika kształtowania się rytualnego chaosu. W: Rytualny chaos. Studium dyskursu publicznego, M. Czyżewski, S. Kowalski, A. Piotrowski (red.), 35-44. Warszawa: Wydawnictwa Akademickie i Profesjonalne.

Polkowska Laura. 2015. Język prawicy. Warszawa: Wydawnictwo UKSW. 
Raciborski Jacek. 2011. Obywatelstwo w perspektywie socjologicznej. Warszawa: Wydawnictwo PWN.

Raport gęgaczy. 2016. O kłamstwach, manipulacjach i prawdziwych zamiarach środowiska PiS. P. Rachtan, A. Czarnecka (red.). Warszawa-Opole: SCRPIPTORIUM.

Rawls John. 1998. Liberalizm polityczny. Warszawa: Wydawnictwo Naukowe PWN.

Sartori Giovanni. 1994. Teoria demokracji. Warszawa: Wydawnictwo Naukowe PWN.

Skarżyńska Krystyna. 2011. Człowiek a polityka. Zarys psychologii politycznej. Warszawa: Wydawnictwo Scholar.

Standing Guy. 2011. Prekariat. Nowa niebezpieczna klasa. Warszawa: Wydawnictwo Naukowe PWN.

Standing Guy. 2014. Karta prekariatu. Warszawa: Wydawnictwo Naukowe PWN.

Stiglitz Joseph E. 2015. Cena nierówności. W jaki sposób dzisiejsze podziały społeczne zagrażaja naszej przyszłości? Warszawa: Wydawnictwo Krytyki Politycznej

Woodward Gary C. 1998. Korupcja dyskursu politycznego: jego cztery odmiany. W: Władza i społeczeństwo, tom II. J. Szczupaczyński (red.), 207-215. Warszawa: Wydawnictwo Scholar.

Żuk Piotr. 2013. Wstęp. Stary autorytaryzm w nowym przebraniu. W: Kulturowo-społeczne uwarunkowania autorytaryzmu, P. Żuk (red.), 7-14. Warszawa: Oficyna Naukowa.

\section{Źródla internetowe}

https://www.gosc.pl/doc/2777841.Internet-w-Polsce-jest-prawicowy [dostęp: 25.08.2018].

http://www.gazetakrakowska.pl/artykul/8866523,prawo-i-sprawiedliwosc-kroluje-w-polskiminternecie-pomaga-w-tym-zdyscyplinowana-armia-trolli,id,t.html [dostęp: 25.08.2018].

https://natemat.pl/210925,platna-prawica-jak-trolle-konserwatystow-i-putina-trzesa-polskiminternetem [dostęp: 25.08.2018].

http://nietylko.natemat.pl/87261,ranking-blogow-politykow-blogerzy-natemat-w-czolowce [dostęp: 25.08.2018].

http://niezalezna.pl/67751-internet-smieje-sie-z-hejterow-platformy-obywatelskiej-obejrzyjmemy-i-wideo [dostęp: 25.08.2018].

http://opole.wyborcza.pl/opole/1,111632,20064486,w-polsce-latwo-zostac-lewakiem-ale-co-toznaczy.html?disableRedirects=true [dostęp: 20.08.2018].

https://natemat.pl/160039,samozwancze-internetowe-wyrocznie-jak-prawicowe-strony-obnazaja -manipulacje-same-manipulujac [dostęp: 20.08.2018].

http://wiadomosci.dziennik.pl/opinie/artykuly/509159,jadwiga-staniszkis-o-trybunale-konstyt ucyjnym-rzadzie-pis-i-andrzeju-dudzie.html?utm_source=powiazane-w-art\&utm_mediu$\mathrm{m}=$ link [dostęp: 25.08.2018].

https:/wpolityce.pl/polityka/340364-prof-glinski-na-kongresie-pwp-bez-archipelagu-polskoscinie-byloby-w-polsce-demokracji [dostęp: 14.11.2018]. 
Adam Bartoszek

\section{THE CRISIS OF THE PUBLIC DEBATE IN POLISH DEMOCRACY AND POP POLITICS}

Summary

This article discusses the symptoms of the crisis in public debate in Poland as an aggressive confrontation of liberal and conservative power elites. The language practices of stigmatising and excluding opponents express the change in the rules of political communication as a result of digital imaging and the replication of new forms of communication. The author expresses the hypothesis of pop politics as a network "profiling of political orientations" in the public discourse through cyber communication and social media. It defines its features as a competitive media spectacle aimed at neutralising political images; discrediting social resistance; and discouraging participation in protests against the authorities. He analyses pop politics as a set of communication practices arising from the contradictions of globalisation processes, neo-liberal economics and the structural decomposition of civic public opinion. It combines the rules of ritualising discourses, seducing the audience with the strength of social resentments, and imitative rivalry and the search for "scapegoats". Political rivals build symbolic domains to identify participants of a cultural community. Polish conservatism has dominated the discourses of pop politics with codes of ethnic patriotism, the affirmation of national traditions and the paternalism of power, which organises the community and provides shelter against multicultural threats.

Keywords: public opinion, political performances, virtualization of discourses, political orientation profiling, symbolic domains, resentment, conservative paternalism 